\title{
An Analysis of Medium of Instruction Policies in the Education System of Pakistan with
}

\author{
Specific Reference to English Medium Education \\ * Sadia Asif, Assistant Professor (Corresponding Author) \\ ** Imran Afzal, Subject Specialist \\ *** Rahat Bashir, Principal Lecturer
}

\begin{abstract}
A critical examination of the trends, issues, and challenges in policy and practice of English language education in Pakistan is the main concern of this paper. This is done first by describing the practice of teaching English in varied instructional situations. Second, the paper historically reviews the language education policies since Pakistan's independence in 1947. Third, the consequences of using English as the medium of instruction are discussed. A longitudinal large scale study is done to highlight the fact that English as medium of instruction at primary school level can distort the teaching and learning activities for students and teachers in rural areas of Pakistan and student dropout rate can even get higher in those areas. The data was collected from the interviews of twenty teachers working in government and semi government schools at primary level. Based on the information obtained from the target participants, teaching at the same level but in different schools, the author argues that mother tongue education at the primary level is the most appropriate method to enhance the educational performance of students and a positive approach to bilingual education must be taken to resolve the challenges associated with the medium of instruction policies in the education system of Pakistan. Moreover, the data also shows that adopting English as a medium of instruction in Public schools may lead to low motivation level among students and it can hinder the development of English as a second language among learners. Furthermore, a difference in home language and school language may also hamper development and concepts formation in students at school level. Therefore, it is recommended that before implementing any language as medium of instruction at school level, one must review the history of Pakistani education system and must keep in mind the linguistic differences of the society and unavailability of resources is also a major hindrance in implementation of any language policy. The results of this study confirm that the pedagogical effectiveness could only be achieved through the mother tongue and provides clear evidence for the usage of native languages as a medium of education in schools.
\end{abstract}

Keywords: Medium of Instruction, Urdu Medium Schools, Bilingual Education, Language Policies, Private Schools

\section{Introduction}

In Pakistan, 57 languages and more than 300 dialects are spoken and Pakistan is linguistically a varied state (Khan, 2002). Table 1 shows the main dialects used in the country and the number of speakers of these languages.

As we can see from Table 1, Pakistan is a country with many languages. Urdu is spoken by $6.8 \%$ percent of the total population. It is the language which is used in the main cities of the country. The official language of Pakistan is English and it was used as an official language even before the independence. English was supposed to continue as the language of official correspondence until Urdu replaces it. However, this never happened, and English is as firmly entrenched in the power circle as it was in 1947.

Nevertheless, Urdu is "the most pervasive lingua franca in Pakistan, both in range and depth" (Harlech-Jones et.al, 2005). Urdu has a strong association with Muslim nationalism and religious portrayal of the state.

\footnotetext{
* University of Management and Technology, Lahore, Pakistan Email: sadiaasif2002@ gmail.com

** Higher Secondary School Kasowal Email: imranafzal148@gmail.com

*** University of Central Punjab Email: rahat.bashir1@gmail.com 
Though English, as the prestigious language, having a negligible amount of proficient users; and it is considered as the most powerful language in Pakistan. The term power is used to define the quality of obtaining more social and worldwide benefits than anyone else. English, as a powerful language, helps its speakers to get higher benefits. The role of English in Pakistan is similar to elsewhere in the world, the language of status, and globalization (Crystal, 2004).

Table 1: Major Languages of Pakistan

\begin{tabular}{cccc}
\hline No & Language name & Speakers(millions) & Percentage of Population \\
\hline 1 & Punjabi, Western & 60.6 & 38.3 \\
2 & Sindhi & 18.5 & 11.7 \\
3 & Saraiki & 13.8 & 8.7 \\
4 & Urdu & 10.7 & 6.8 \\
5 & Pashto, Northern & 9.6 & 6.1 \\
6 & Pashto, Central & 7.9 & 5.0 \\
7 & Balochi, Southern & 2.8 & 1.8 \\
8 & Brahui & 2.0 & 1.3 \\
9 & Hindko, Northern & 1.9 & 1.2 \\
10 & Balochi, Eastern & 1.8 & 1.1 \\
11 & Farsi, Eastern & 1.0 & 0.6 \\
12 & Punjabi, Mirpur & 1.0 & 0.6 \\
13 & Pashto, Southern & 1.4 & 0.9 \\
14 & Balochi, Western & 1.1 & 0.7 \\
& Sub-total & 134.1 & 84.8 \\
& 58 other languages & 24.0 & 15.2 \\
& Total & 158.1 & 100.0 \\
\hline
\end{tabular}

Note. Adapted from: Coleman (2010, p.13)

There is a huge demand for English in the education of Pakistan from all sections of society. Therefore, reading and writing in English is required as a pre-requisite for the socio-economic development of individuals and the nation (Shamim, 2007).

Proficiency in English and Urdu is required to be a progressive part of Pakistani society. However, this essay highlights the reality that English is considered to be more influential and is given more importance in Pakistan than any other language on the basis that it promises greater economic and personal development and acts as a gatekeeper to highest economic gain (Mansoor et al., 2005). This phenomenon has led to the popularity of English used as an instructional language in schools. The paper begins with a brief introduction to the system of education in Pakistan, continues with the history of language development, and then moves on to a detailed observation of issues and challenges faced by English in the education system. This essay traces the controversies and explores the historical backgrounds and various reasons for choosing a language that will serve as an instructional language in our Pakistani context. It also analyses the current policy of language in Pakistani education that is intended at achieving majority literateness in the English language as well as other subjects, by considering mainly at plan aims, implementation strategies, and outcomes. Information is given on the fluctuations in language policies implemented by different governments in their tenure. Next, the paper highlights the concerns of using English as a medium to teach all subjects in the curriculum and demonstrates that despite all efforts, school and university graduates are not able to keep up the pace and demand required for proficiency in the language which is foreign to the majority of Pakistani population. Taking into account the linguistic plurality of Pakistan, the paper suggests that several factors should be analyzed before declaring English as a language of instruction at the early education level that is Primary; the higher-level education is already English. Finally, the paper argues that maintaining literacy in the first language is very important, at least at the school level, if there is to be any significant improvement in education standards nationwide. The article is also offering few suggestions based on improving the status quo for better inclusion of students based on Adamson and Feng's (2015) generalization of Trilingulism in education model.

\section{Literature Review}

This section reviews the different types of educational institutions found in Pakistan and the languages used by them as the medium. It also examines data related to the participation of learners in the Pakistani education. 
Pakistan has the highest student drop-out rate in the region: over $50 \%$ of pupils in public schools do not finish the early education of their school. Table 3 shows the drop-out rates in different types of schools, by region and gender. This high drop-out rate is attributed to the medium of instruction used by many teachers and students. However, Swada and Lokshin (2001) state that Pakistani household is incredibly poor in rural areas and consequently, male members of the family do not go school but try to earn income for the family and that causes high drop out for males and is related directly with child labor. Holmes's (2003) study indicates that overall, females get fewer opportunities than males in Pakistan. In Pakistan the Private schools are generally expensive and fulfill the need of rich segments of the society; these households have predicted permanent income, therefore, the dropout rate for expensive schools is considerably low as compared to the government schools.

Table 2: Percentage of Participation

\begin{tabular}{lccc}
\hline & Boys & Girls & Cumulative \\
\hline Primary Level (NER) & 73 & 59 & 66 \\
Secondary Level (NER) & 36 & 28 & 32 \\
Tertiary Level (GER) & 6 & 5 & 5 \\
\hline
\end{tabular}

Note. Source: UNESCO (2007)

Table 3: Drop-out rates by type of schools, region and gender

\begin{tabular}{ccccccc}
\hline Types of school & \multicolumn{2}{c}{ Urban } & \multicolumn{2}{c}{ Rural } & \multicolumn{2}{c}{ All areas } \\
\hline & Male & Female & Male & Female & Male & Female \\
Government & 26.9 & 20.1 & 24.7 & 26.9 & 25.3 & 24.2 \\
Private & 17.4 & 10.0 & 12.1 & 7.8 & 15.4 & 9.2 \\
\hline
\end{tabular}

Note. Adapted from Bilquees \& Us-Saqib (2004, p. 13)

Pakistan's education system is divided into two distinct streams based on the language of education. Throughout the country, the English medium and Urdu medium run side by side. For the most part, Urdu-medium schools are government-owned public schools where English is taught as a subject, and Urdu is used to teach different subjects as well as of communication. The education is free and textbooks are arranged for students at no cost. Such schools are available throughout most of the country (Coleman, 2010). According to Rahman (2004) students in public schools rely heavily on rote learning, and analysis by the student is not cultivated in them. Moreover, the facilities are very poor in these schools.

It is apparent from the data presented in Table 4 that the student/teacher ratio in public schools is high as compared to private schools. Moreover, they even lack in the provision of basic facilities for their students. Coleman (2010) notes that though public schools are free, textbooks are provided and public school teachers are better paid than others. It is reported in the

Table 4: Private Compared with Public Schools

\begin{tabular}{lcc}
\hline \multicolumn{1}{c}{ School Characteristics } & Public Schools & Private Schools \\
\hline Mean Student-Teacher Ratio & 42.7 & 24.8 \\
\% Schools having Toilet Facility & 48 & 84 \\
\% Classrooms with Desks in a School & 40 & 80 \\
\% Classrooms that are unusable in a School & 24 & 12 \\
\hline
\end{tabular}

Note. Adapted from: Andrabi, Das \& Khwaja (2002, p.20)

These factors generally contribute to the widespread belief that private schools, commonly known as English medium schools, impart better education than public schools.

The expensive private schools are normally present in localities where people can afford to pay high fees. Some of these private schools sell their English language education at a very high price to the children of the upper-middle-class and above (Rahman, 2004)

Private schools can be separated in these two categories; a) the private elite English medium and b) the private non-elite English medium schools. The former is extremely expensive and cater only those who can afford to pay. Only a small section of the society, mainly powerful elites, have their children in these schools. In contrast, the less expensive English medium schools are very large in number and rapidly growing in different parts of the country.

Moreover, "the majority of these private schools are catering more to the lower and middleclass income group, rather than rich elite" (Andrabi et al., 2002, p.14).

Students in private-elite English medium schools are different academically and the difference can be attributed to the difference in the availability of funds and the opportunities for 
English language practice available to students in both schools. The students of private schools come from rich households and are more exposed to the western world and media, therefore, they get more opportunities to communicate in the English language at home, school, and even outside in their community, which is not the case for those in non-elite private schools.

Table 5: Annual fees in Rupees for private primary schools in urban areas

\begin{tabular}{cccccc}
\hline Province & Median & Mean & $\begin{array}{c}\text { Standard } \\
\text { Deviation }\end{array}$ & $\begin{array}{c}\text { Inter- } \\
\text { quartile } \\
\text { range }\end{array}$ & $\begin{array}{c}\text { Number of } \\
\text { schools }\end{array}$ \\
\hline NWFP & 1342.85 & 1688.56 & 2160.58 & 914.39 & 533 \\
Punjab & 850 & 1286.94 & 3331.34 & 661.13 & 4201 \\
Sindh & 129718 & 1950.62 & 3375.17 & 1175.33 & 1290 \\
$\begin{array}{c}\text { Baluchistan } \\
\text { Islamabad }\end{array}$ & 1740.98 & 2095.64 & 2327.21 & 1200 & 61 \\
Northern & 3390.91 & 4791.86 & 4941.39 & 2940.1 & 50 \\
Areas & 2688 & 5543.68 & 5800.98 & 2183.76 & 5 \\
Azad & 1541.9 & 2138.75 & 3793.97 & 992.31 & 110 \\
Jammu & & & & & \\
Kashmir & & & & & \\
(AJK) & & & & & \\
\hline
\end{tabular}

Note. Adapted from: Andrabi et al., (2002, p.14); Exchange Rate: Pak Rs. 85 = CAD 1.

The poor learning outcomes of certain schools in Pakistan can be seen as a result of hiring incompetent teachers or inadequate school facilities, but one of the main reasons is also the language policies executed in the education division by our government in all these years.

There have been statements about language policy in various documents in Pakistan. This section provides a brief historical overview of language education policies in Pakistan. The focus is primarily on the use and importance of Urdu and English.

Mahajirs supported Urdu to consolidate their power at the federal level and also declared Urdu as a symbol of Pakistani identity. On the other hand, Bengali was the only dominant language spoken in East Pakistan at that time. The language of instruction in academia of East Pakistan was Bengali and it had widespread usage in the official circles too. Urdu was greatly opposed by them as it undermined the significance of Bengali. Moreover, Urdu was seen as a symbol of Punjabi dominance as most of its speakers were from the Indian Punjab. Therefore, the declaration of Urdu as the national language left a bad taste in Bengalis and became later on a reason for the separation of East and West Pakistan.

In 1958, Ayub Khan, introduced Cadet Colleges to produce students who would be future leaders and military officers (Rahman, 2005). Thus, the two streams of education, elite for English medium and non-elite for Urdu were established in the country and reinforced divisions in society.

There was a sudden change in the language policy during Bhutto's government in 1973 when the constitution of Pakistan stated Urdu as the sole national language and it was recommended that in the next 15 years Urdu will replace English. This change in policy is attributed to Ayub Khan's proEnglish bias, another reason for the importance given to Urdu.

In 1977 Zia-ul-Haq, took over the matters of the Pakistani government. In his regime, there was a revitalization of the Urdu language as the language of Muslim identity, a symbol of the Pakistani movement, and the language of unity (Haque, 1993; Rahman, 1996). However, due to parental demands, English was still popular among the society and English medium schools were in high demand. Moreover, it is important to note that Zia-ul-Haq himself could not eliminate the use of English in schools and government circles because of the pressure from westernized elites. A setback to the 1979 policies was Zia's detour from his staunch advocating of Urdu by giving legal protection to schools tutoring for American or British High School examinations. Thus, the education policy of 1979 was quietly reversed.

In 1989, the newly-elected Prime Minister Ms. Bhutto proclaimed that English should be the language of instruction from Grade 1 in all public schools, having previously been taught from Grade 4. The policy was implemented immediately without any well-defined strategies. The next elected government of the Muslim League led by Mian Nawaz Sharif had an indifferent attitude towards these policies in education and there was no change in policy during his era. However, private schools kept on growing during this period. In 1999, when General Musharraf took care of the country's 
government. Though there were many pro-English stances in various statements of government officials, there were little concrete struggles to mend the teaching and learning plight of the English language or Urdu language in schools in Pakistan.

The above discussion shows that the only major change that occurred in the language policy of education was the introduction of English in Grade 1 rather than in Grade 4. No emphasis has ever been given to regional or local languages in the education system despite the rhetoric of the constitution. The development of education policies is summarised in Table 6.

The Ministry of Education of Pakistan has freshly hand out a document called "Education in Pakistan: A White Paper - Document to Debate and Finalize the National Education Policy". The document is going to serve as a pre-policy document to arouse a debate on policy issues regarding education in Pakistan. There was a long review of this process that started in 2005 and is still in review and is changed according to the requirement and earlier it was finalized in 2007 as a White Paper. This is the basic of all the development in the education sector. Therefore, the recent revised White Paper, the same in content to initial policy paper, on education policies recommends that English must be taught as a subject from Grade 1 and Science and Maths should be taught in English too from 2014 for all (Aly, 2007). The discussion in this paper will analyze the consequences of this decision in the upcoming sections.

The issuance of this recent document by the government of Pakistan opens up a detailed debate about the potential benefits and consequences of using English as a language of instruction which are discussed below:

Table 6: The evolution of language in education policy of Pakistan

\begin{tabular}{|c|c|c|c|}
\hline Year & Event & Policy & Implementation \\
\hline Pre-1947 & Colonial rule & $\begin{array}{l}\text { Urdu medium for masses, English } \\
\text { medium for elite }\end{array}$ & As policy \\
\hline 1947 & Independence & $\begin{array}{l}\text { Urdu declared to be the national } \\
\text { language }\end{array}$ & $\begin{array}{l}\text { Urdu medium for masses, } \\
\text { English medium for elite }\end{array}$ \\
\hline 1959 & Sharif Commission & $\begin{array}{l}\text { Primary and secondary education } \\
\text { in Urdu, higher education in } \\
\text { English }\end{array}$ & No change \\
\hline 1973 & New constitution & $\begin{array}{l}\text { English to be replaced by Urdu } \\
\text { within } 15 \text { years; provinces free to } \\
\text { develop their language policies }\end{array}$ & No change \\
\hline 1977 & Coup by Zia-ul-Haq & Islamisation and Urduisation & $\begin{array}{l}\text { English taught from Year 4; } \\
\text { schools begin to prepare for } \\
\text { complete Urduisation of exams } \\
\text { by } 1989 \text {; private English } \\
\text { medium schools begin to grow }\end{array}$ \\
\hline 1989 & Benazir Bhutto elected & English to be taught from Year 1 & Little effective change \\
\hline 1998 & New education policy & $\begin{array}{l}\text { No statement regarding language } \\
\text { policy }\end{array}$ & $\begin{array}{l}\text { Private English medium } \\
\text { schools flourish }\end{array}$ \\
\hline 1999 & $\begin{array}{l}\text { Coup by Pervez } \\
\text { Musharraf }\end{array}$ & $\begin{array}{l}\text { English to be taught from Year } 1 \\
\text { 'where teachers are available' }\end{array}$ & Little effective change \\
\hline 2007 & White Paper & $\begin{array}{l}\text { English to be taught from Year } 1 \text {; } \\
\text { mathematics and science to be } \\
\text { taught through English from Year } \\
6\end{array}$ & $\begin{array}{l}\text { Little effective change; in } \\
\text { Punjab science taught through } \\
\text { English from Year } 10\end{array}$ \\
\hline 2009 & $\begin{array}{l}\text { National Education } \\
\text { Policy }\end{array}$ & $\begin{array}{l}\text { Science and mathematics to be } \\
\text { taught through English in Years } 4 \\
\text { and 5; all science and mathematics } \\
\text { to be taught through English from } \\
2014\end{array}$ & $\begin{array}{l}\text { Punjab declares science to be } \\
\text { taught through English starting } \\
\text { in Year } 4 \text { from April } 2009\end{array}$ \\
\hline
\end{tabular}

Note. Adapted from: Coleman (2010, p.15).

\section{Methodology}

The present study is part of the findings that have been derived from a longitudinal study. In this study the qualitative data was collected from 20 primary school teachers teaching in different government and semi government schools. Their interviews were recorded and then they were transcribed by the researcher. All the teachers who participated in the study were able to speak Urdu and English 
language, however they had different mother tongues including Punjabi, Saraiki, Sindhi and Pushto. All of them were asked same question to evaluate the use of Urdu and English as a medium of Instruction at primary level. The teachers were different in terms of age and linguistic abilities and their ages fall in the range from 50 to 30 years. All these teachers had a lot of teaching experience in hand and none of them had teaching experience less than five years. Since these teachers had diverse socio-linguistic background, education level, age, personality trait, attitudes and proficiency level in both Urdu and English, their comments, views and responses to the interview questions contributed a lot to this study. Therefore, the researchers got first-hand knowledge of a wide belief that method of teaching in education policy can sometimes act as a tool to figure out which social and linguistic groups can have access to political and financial chances (Phillipson,1992, 2001; Tsui \& Tollefson, 2004), and it can also accelerate the phenomenon of "linguistic genocide" (Skutnabb-Kangas, 2000, p.24) in a multilingual society. To strengthen a language and its speakers, as well as to increase the status of a language, it is important to give that language some share in the education system. One way to promote and preserve the languages of Pakistan would be to use them as a medium of education at least at the primary level in their respective domains or regions. The data obtained through interview was triangulated and analyzed with the help of policy papers, research articles, news material and scholarly content analysis

\section{Results and Discussion}

According to the views of the participants, in Pakistan, the linguistic hierarchy is as follows: English, Urdu, the local language. In the KPK and Sindh, Pushto and Sindhi languages are spoken respectively; these languages are seen as identity markers by their speakers, so they use these languages in an informal context, however, much adulterated with Urdu and English words. In Punjab, sadly, there is a broad culture-disgrace about the Punjabi language. Guardians, educators, and the friend bunch consolidate to humiliate understudies about Punjabi. In the entirety of the elitist English-medium schools, it can be commonly observed that if someone speaks Punjabi, he or she is called "Paindu" (rural, village yokel) and made fun of (Rahman, 2005). Many educated parents communicate in English or Urdu as opposed to Punjabi with their kids. These mentalities are having a crushing impact on Pakistani languages.

There are more than fifty small languages of Pakistan, for the most part in Northern Pakistan, which are feeling the squeeze. Acquiring from Urdu and English has settled in the negative prospects for these endangered languages. Balochi and Brahvi, for instance, are little dialects under much pressure from dominant languages. As neither of these dialects is utilized in the spaces of intensity and they will make due as casual dialects in the private area only. Similarly, in the city of Karachi, the Gujrati language is being abandoned, in any event in the composed structure, as youngsters try to be proficient in Urdu and English - the dialects utilized in power. A reason for this language shift is that many of the speakers of these languages do not want to be taught in their regional languages because they believe that it is not economically helpful for them (Mansoor, 2005).

Furthermore, forces of globalization and modernization have accelerated the death of languages that have survived for millennia for formal education. Parents also believe that they are helping their children best by speaking the dominant language to them be it Urdu or English depending on the region or context. They learn through their experience that it is necessary to choose between languages. Another reason for the negative attitude towards regional languages is the failure of job seekers in respect of finding employment when furnished uniquely with the information on their first language. As a result, first languages are trashed as being confused for most employments in Pakistan. Moreover, interests in first languages are uncommon, as they don't include high on the government schema. Help is absent, both as far as financing and policy enforcement, which has been felt for a long time, is as yet the case.

The participants of the study highlighted that many parents, and authorities compare the nature of education just with ability and capability in the English language, which is supported by the government of Pakistan in its language policies. This is, however, a false notion because other factors such as availability of teaching resources, teaching-learning strategies used in the classroom, and the competency of instructors to communicate in the English language are also involved in an assessment of the quality of education.

For example, Shamim (2008) emphasizes that there are subjective and instructive results of learning ideas in English, which is the third or fourth language of youngsters in Pakistan. Utilization 
of English urges students and educators to adapt by utilizing procedures, for example, code exchanging in the study hall, and debilitates the utilization of request based methodologies for instructing and learning, as students tend to be silent in the class. This reflects experience in other countries. Arthur (2001) has discussed the classroom practices that are used for effective implementation of educational language policy in his study of Botswana and Tanzania. He concludes that reliance on teacher-centered recitation routines and code-switching weakens the quality of education. Brock-Utne and Holmarsdottir's (2004) research project also analyzes the language policies of Tanzania and South Africa and their practices in the classroom. They note that codemixing and translation are common phenomena in both countries which have led to the academic failure of many African students.

One teacher participating in the study says that Educators play a central part in the execution of language policy and the nature of teaching, but in many rural contexts, neither teachers nor students are experts in the English language (Jalal, 2004). The vast majority of Pakistani teachers are non-local speakers of the English language who, rather than being true bilinguals, are monolinguals with some abilities and information in the objective language (English) likewise to their first language (Gulzar, 2010). The essential capability for an elementary educator is to matriculate (Grade 10) with a Primary Teaching Diploma in many parts of the country. For middle schools, it is intermediate (Grade 12) with a Diploma in Teaching and for secondary education and higher secondary, it is Bachelor of Education (B. Ed) and Masters Degrees individually. There are no clear policies and requirements for language proficiency tests for teachers, and no in-service teacher development resources.

Professional capabilities of educators are a basic issue in Pakistan. Ineffectively qualified instructors unquestionably add to the low fitness and capability in English accomplished by their students. Shamim (1993) closely observed the 33teaching and learning of English language in ESL classes of various sizes in government and non-tip top tuition-based schools in Pakistan. Her discoveries uncovered that instructors in English study halls focused basically on "doing an exercise" or "doing grammar". "Doing a lesson" consisted of a specific arrangement of movement types; for instance the tutor or the student perusing the content resoundingly, clarifying a similar book in Urdu or the nearby language, underlining troublesome words and providing the meaning for those words in Urdu or the native language and finally asking students to do follow-up course reading practices in their note pads. Also "doing grammar" signifies educating and learning a language thing without setting, with an emphasis on structure in particular, and composing articles, letters, etc. Furthermore, because of the low capability of English among instructors and students, the majority of teachers dictate a lot of articles and letters or keep in touch with them on the slates for the understudies to duplicate in their scratchpad so understudies could become familiar with these expositions by heart and could create them in the assessment (Shamim, 1993, p.187-193).

In other subjects, Halai $(2007,2008)$ showed that in mathematics classrooms where gathering work and social connections were advanced and English was used as a language of learning, students as well as teachers deciphered to and fro between the language of guidance and the students' national language (Urdu). This interpretation was especially obvious when understudies worked with one another in little gatherings, and in circumstances where understudies were announcing their gathering work to the entire class or where they associated with the educator. Jan (2003) affirmed the prior investigations by Halai yet with regards to science teaching. He observed classrooms in which the school strategy of teaching science in English as a method of teaching was followed. He investigated how learners of Grade 8 from a non-elite private school, situated in the city of Karachi, understand the nature of science in an L2 medium. He observed that the instructor and the learners depended on interpretation into Urdu of certain key thoughts and ideas. Similarly, Panah (2000) concentrated on primary school science educators' observations and work on concerning showing science through English. This research was conducted in a primary grade science classroom at a private English medium school in the context of Karachi. He saw that instructing science through a foreign language was very challenging when the learners couldn't convey in light of the absence of language capability. In that circumstance, youngsters couldn't take an interest in study hall exercises and became aloof audience members, and instructors just gave addresses and made an interpretation of the reading material into the kids' language. As understudies couldn't communicate in English, during study hall instructing and in the assessment, they depended on repetition retention. 
Pakistan has been battling to locate a powerful methodology that can permit it to move from the instruction framework acquired from the British principle to a progressively transformative and significant training that contemplates Pakistani qualities and dialects. Based on the analysis of the problems associated with English-medium education in the previous sections, I maintain that such a pertinent and successful education strategy would be portrayed by the utilization of a proper method of teaching. Concerning Pakistan, the most reasonable medium of teaching is the student's mother tongue. Conveying education in various dialects is more difficult than doing as such in only one language, nonetheless, an arrangement of primary language instruction in the early long periods of training doesn't infer that each indigenous minority language should be included. As Table 1 shows that $85 \%$ of the school populace in Pakistan would be secured by only seven significant dialects, the methodology could be reached out to some minority dialects with the section of time as the education system became more confident and experienced.

Researchers who have examined the psycholinguistic advancement of youngsters accept that language and psychological improvement are personally related. It is easier for a child to learn, express, and produce creative ideas in his/her mother tongue rather than an alien language. The term mother tongue refers to the first language that a kid gets in an informal setting (Nekatibeb, 2007). Teaching in mother language takes education inside the range of more youngsters, and raises their confidence in expressing their opinions in class. Kids make more noteworthy progress in education, at least during the first years of primary education, when they study in their mother language. Evidence for this comes from research in a variety of countries. A study in Madagascar (Komarek,1997) showed that students taught in their mother tongue performed better in elementary reading and writing classes after a year of experiment and achieved a $15 \%$ lead over students in a school where the language of instruction was not Malagasy, the students' mother tongue. It can be concluded that higher academic performance and improved problem-solving skills are a direct result of teaching in the mother tongue.

Similarly, Nekatibeb (2007) has studied the various factors which affect the quality of education and students' achievement in Ethiopia. He grouped these factors into six classifications for numerous relapse investigations i.e,. to inspect the degree to which a change in an independent factor affects student's achievement. According to his conclusions, the second most influential characteristic is the language of instruction. This is shown in Table 7.

The data in Table 7 illustrates that all these factors aggregated together constitute 55\% of the maximum total variance. Variance can be defined as the maximum deviation or the spread of data from the mean or the average value. It can be seen that student background explains $38.6 \%$ of total variation and language of instruction comes next with a variation of $37.3 \%$ in student's achievement. Table 7 reinforces the point that the language of teaching in schools affects the quality of education.

Nekatibeb's (2007) study used data from the Ethiopian Second National Learning Assessment to compares the learning performance of students who studied various subjects by the method of their mother language with those who studied the same subjects through a foreign language. It tends to be seen that learners who learned other subjects by the medium of mother language scored an average of $42.30 \%$ whereas learners who studied by a non-mother language scored $36.23 \%$. The results confirm the pedagogical effectiveness of learning through the mother tongue and provide clear evidence for the usage of native languages as a medium of education in schools.

Table 7: Multiple regression analysis of variables and their relationship with composite student achievement in Grade 8

\begin{tabular}{cccc}
\hline Categories of variable & $\mathrm{R}$ & $\mathrm{R}-\mathrm{sq}$ & $\mathrm{F}$ \\
\hline $\begin{array}{c}\text { Student's background } \\
\text { and behaviour }\end{array}$ & 0.404 & 0.386 & $22.42^{* * * *}$ \\
Language of instruction & 0.611 & 0.373 & $125.51^{* * *}$ \\
Teacher & 0.570 & 0.325 & $16.37^{* * *}$ \\
School structure and & 0.453 & 0.205 & $8.32^{* * *}$ \\
curriculum materials & & & \\
Instruction/support & 0.368 & 0.136 & $7.30^{* * *}$ \\
School management & 0.366 & 0.111 & $5.73^{* * *}$ \\
\hline
\end{tabular}

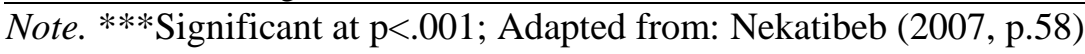


Table 8: Composite student achievements in learning other subjects with mother and non-mother tongue

\begin{tabular}{ccc}
\hline Medium & Number of Students & Mean Score \\
\hline Mother tongue & 3256 & 42.30 \\
Non-mother tongue & 4534 & 36.23 \\
Mean difference & - & 6.06 \\
\hline
\end{tabular}

Note. Adapted from: Nekatibeb (2007, p.56).

The evidence thus suggests that the quality of public schools can go up if they instruct in the mother language of the learners who are registered in them as this will help students to thoroughly understand the curriculum and thus raise their academic skills. Moreover, early concept formation is more effective and long-lasting in one's mother language since there are no boundaries to understanding (Coleman, 2010). Kids can integrate their life experiences with classroom learning and can relate the education, which they get in school, to the lives they live at the house.

Turning to the Pakistani experience, Capstick (2011) also believes that lack of mother tongue education results in weak cooperation rates in education in Azad Jammu Kashmir, Pakistan. He cites a Save the Children report which argues that: Huge scope examination of cooperation in instruction is indicating that whether a youngster is educated in their first language or native language, regularly strongly affects whether a kid goes to class, especially in country territories. The language used to convey the school educational program pulls down the instructive execution of a large number of the individuals who don't utilize it at home, especially the individuals who don't have normal access to it outside school (Pinnock, 2009 cited in Capstick 2011 p. 15).

The historical experience of the region shows that in the eighteenth century the literacy rate in Lahore, a major city of Pakistan, its neighborhood was about $80 \%$, which is down to single digits now. The proficiency rate plunged because the mode of instruction was transformed from the primary language to Urdu and English. Some English government workers had anticipated the outcomes of not making the first language the vehicle of instruction. They contended that when Latin was the vehicle of training in England, the instruction was constrained to limit circles. In any case, when French was embraced as a vehicle of training, the proficiency rate extended a piece, however mass instruction was made conceivable just when the Celtic lingo, received as Standard English, was made the mode of instruction (Rahman, 2003). Brock-Utne (2000), a main supporter of education through indigenous dialects in African countries, challenges the view that English ought to be utilized as the mode of instruction in Africa, especially in the early years of education. She states that as long as African countries continue to teach their upcoming generations essentially through foreign dialects, they will never enjoy the liberty of thought and expression. She asserts that "education for liberation and self-reliance must begin with the use of a language that does not thwart the acquisition of conceptual knowledge. This is a true challenge for many post-colonial countries in Asia and Africa" (BrockUtne, 2000, p.173). The same challenge exists for Pakistan.

\section{Recommendation}

At the official level, Pakistan desires to move to English medium education in its primary schools, yet this does not seem to be in the best interests of all children. A better strategy would be to promote Urdu and regional languages side by side while simultaneously supporting the learning of English. This is only possible if all the languages are included in the education system of Pakistan. The strategic procedure best suited to meet the needs of the Pakistani education system is an idealized policy devised by Coleman (2010) in his report for language in education in Pakistan outlined below:Nursery Education: Study to rhyme, express in mother language

First 3 years: Introduction to alphabets, learn to read and write in the mother tongue.

Class 3-5: Urdu is introduced and gradually replaces regional language as the language of instruction. By grade 5 this transition is complete. Regional language is taught as a subject.

Class 6: Children fluent in Urdu by now. English is introduced. English is studied as a main subject for four years from grade 6 to grade 9 .

Class 10: English becomes a medium of instruction; Urdu and regional languages become subjects.

International experience provides support for the successful implementation of multilingualism in the education systems of various countries in the world. Tucker (1998) has given examples of these countries. Tucker (1998) states that in the Philippines, after experimenting with various education models, policymakers have finally decided to sustain a bilingual or sometimes even 
a trilingual system of education to promote their two official languages, i.e., English and Filipino. According to his research, the success story is replicated in Guatemala where bilingual education projects have brought about a remarkable reform in the system. Spanish is the official language in the country but more than half of the population speaks Mayan. Therefore, Mayan has been adopted as the medium of teaching in primary schools and Spanish announced as a subject later in secondary school. The success of the project has persuaded the Ministry of Education to formalize this system. Namibia is another country in the introductory stages of implementing a bilingual education policy in its school systems, having used English as a mode of teaching since independence.

Nursery education assumes a crucial job in improving the certainty of the youngsters express opinions in class. When the child speaks the mother tongue at home and school, he/she does not face any problem while expressing opinions at school. The gradual transition from mother tongue to Urdu and then to English will help students to be fluent verbally and in written expression in these languages. In this manner, every child will acquire language skills in three different languages. It will help preserve all the regional languages in Pakistan, as every language will be taught in schools in different regions. Once a language becomes part of the education system, the danger of its extinction is eliminated.

The major problem associated with this proposal is the reaction of communities living in Pakistan to this multilingual approach. It can be predicted that certain communities and the education authorities will oppose this idea based on the inconvenience it will cause by integrating several languages in the education system. Moreover, there are worries that the policy may lead to ethnic disintegration (Malone, 2003, p. 6). However, the international experience shows that the appropriation of numerous dialects in elementary school education really will in general reinforce the steadfastness of ethnic minorities to the state, since every ethnic gathering see that they are as a rule similarly regarded. Switzerland and Singapore are the successful and well-established examples of such an education system. Furthermore, preparing instructors and getting ready course books in a few dialects is unmistakably more costly than doing as such in only one language. Be that as it may, giving essential training to huge quantities of kids who drop out ahead of schedule and who gain practically irrelevant degrees of proficiency and numeracy while they are in school is much increasingly costly. These are the most currently debated issues in countries where mother tongue education is in the process of being implemented. If we take a look at international policies implemented to counteract these problems, these fears can be allayed.

It is natural for the education authorities in Pakistan to be concerned about the initial costs expected to be incurred in the curriculum development process. But in the context of Pakistan, one must look past the quick expense and think about the eventual fate of the nation. Though there is the possibility of one-time additional start-up costs, research done throughout the world indicates that such inventive programs cost about equivalent to traditional programs in the long run (Smith, 2003). The training of teachers and translation of a wide range of textbooks in multiple languages may be expensive, but the cost of a large number of kids who drop out early and gain irrelevant degrees of education is even greater (Coleman 2011).

The notion that encouraging the usage of native languages in education may give rise to ethnic disintegrations is a common misunderstanding in Pakistan. A look at later and current history shows the inverse is all the more regularly obvious: it is when neighborhood language and ethnicity are smothered that individuals are bound to revolt. Malone (2003) supports these viewpoints by giving examples of the Lithuanians, whose outrage regarding the required utilization of Russian in their schools was an early factor prompting their break with the Soviet Union. Also, Catalonians are even now fomenting against what they see as the Spanish government's etymological and social colonialism. Malone has compared these circumstances with Papua New Guinea where the administration has started early instruction in more than 300 of the nation's 820 dialects. Papua New Guinea celebrates as opposed to laments its decent variety, as confirmed by John Waiko, the former Minister of Education when he states that: Our greatest national resource is the diversity of cultures in our country. Diversity means more viewpoints to clarify, more ways of solving problems, more creative ideas, a greater ability to deal with change... Where diversity is crushed...the nation becomes weak and divided. (Malone, 2003, p. 6).

Hence, the evidence indicates that the propagation of regional languages not only preserves and promotes ethnic cultures and heritage, but also integrates minorities into mainstream society. 
Similarly, in Pakistan groups that have emerged based on linguistic issues alone will gradually start to decline in number as the government itself will be promoting all languages in the education system. Such policy will also help to create impeded gatherings to be on a standard with major financially advantaged bunches inside Pakistan's multi-ethnic culture. According to a study conducted by Smith (2003) in Malaysia, in additive bilingual education programs, where the mother language is used as the language of teaching in the schoolroom in the early years, minority-language students become increasingly effective learners at a later stage. Thus, if this type of educational system is established in Pakistan, it will help in enhancing the literacy rate of the country.

\section{Conclusion}

In Pakistan, only six percent of the populace has an approach to education in their first language, and the rest of the population, who speak several languages, have no share in the education system of Pakistan. Though education at the primary level in different dialects is going to be strategically troublesome, it isn't incomprehensible.

The integration of several languages within the education system is only possible, however, if the local community realizes that there is a need to have a firm grip on the management of language programs. Implementation of the policy will not be a complex matter for education authorities if they have the support of the community. Stroud (2007) believes that the integration process will be successful if designed and managed by the community. Concerning the integration of a curriculum designed in regional languages, Clegg (2007) speaks of the standardization and revitalization of local languages. He stresses that teachers should be trained in teaching in regional and second languages, and should be aware of the importance of bilingual education. Teaching material should be collected and written in regional languages, and the interest of the local community should also be engaged to use these languages at home. Although 72 languages are spoken in Pakistan, $85 \%$ of the population speaks seven major languages that have their orthographic system in place, so developing materials in these languages and training of teachers will be costly but not impractical. In this manner, at least we can guarantee that mother language teaching is best for the most, if not for all.

The experience of so many decades is an eye-opener for educational reformists in Pakistan, who propagate the use of English as a mode of teaching in schools from the primary level. It is time to accept that education in English from the primary level is not working in Pakistan. This opinion is also shared by researchers like Clegg (2007) who believe that school achievement can only be raised through teaching in mother tongues and that there is an urgent need to bring our regional languages into our learning system.

The instructive system in Pakistan needs an overhaul, but even before that, we need to eliminate the notion that without English medium we cannot forge ahead in the modern world. I do not wish to demean the value of English as a global language, but this status does not entitle English to take the place of the native languages of any country. Similarly, globalization should not mean the elimination of cultural diversity and the adoption of one uniform culture.

Pakistan has not made any significant progress in education over the last two decades despite having English as the main media of education in an enormous number of schools and colleges. Ironically, these supposed English medium schools and colleges have more likely contributed to lowering the standards of education in Pakistan as children have been required to learn in a non-native language, which has led directly to poor understanding of curriculum content and correspondingly poor achievement.

In conclusion, the foremost priority for education in Pakistan is to promote bilingual education through strategy discussions and bringing issues to light of the significance of native language education in the early long periods of tutoring rather than wasting effort and resources on the illusion that English medium education at the primary level will bring educational advancement and prosperity to the whole country

\section{References}

Adamson, B., \& Feng, A. W. (2015). Trilingualism in education: Models and challenges. In A. W.Feng \& B. Adamson (Eds.), Trilingualism in education in China: Models and challenges (pp. 243-258). Springer.

Aly, J. H. (2007). Education in Pakistan: A white paper (revised). Ministry of Education. http://planipolis.iiep.unesco.org/upload/Pakistan/Pakistan\%20National\% ss20Education\%20Policy\%20Review\%20WhitePaper.pdf 
Andrabi, T., Das, J., \& Khwaja, A. (2002). The rise of private schooling in Pakistan: Catering to the urban elite or educating the rural poor. World Bank and Harvard University. http://economics-files.pomona.edu/Andrabi/Research/Pakschool\%20March29.pdf

Arthur, J. (2001). Perspectives on educational language policy and its implementation in African classrooms: A comparative study of Botswana and Tanzania. Compare, 31(3), 347-362.

Bilquees, F., \& Us-Saqib, N. (2004). Drop-out rates and inter-school movements: Evidence from panel data. Pakistan Institute of Development Economics Islamabad. http://www.sanei network.net/

Brock-Utne, B. (2000). Whose education for all? The recolonization of the African mind. Falmer Press.

Brock-Utne, B., \& Holmardottir, H.B. (2004). Language policies and practices in Tanzania and South Africa: Problems and challenges. International Journal of Educational Development 24(1), 67-83.

Capstick, T. (2011). Language and migration: The social and economic benefits of learning English in Pakistan. In H. Coleman (Ed.), Dream and realities: Developing countries and the English language education. British Council. Available online at www.teachingenglish.org.uk.

Clegg, J. (2007). Moving towards bilingual education in Africa. In H. Coleman (Ed.), Language and development in Africa and beyond. (pp. 49-64). British Council.

Coleman, H. (2010). Teaching and learning in Pakistan: The role of language in education. British Council. http://www.britishcouncil.org/pakistan-ette-role-of-language-in-education.

Crystal, D. (2004). The language revolution. Polity Press.

Government of Pakistan. (2005). National education census. Statistics Division, Federal Bureau of Statistics. http://www.statpak.gov.pk/depts/fbs/publications/ nec2005/nec2005.html.

Gulzar, A.M. (2010). Code-switching: Awareness about its utility in bilingual classrooms. Bulletin of Education and Research, 32(2), 23-44.

Halai, A. (2007). Learning mathematics in English medium classrooms in Pakistan: Implications for policy and practice. Bulletin of Education and Research, 29(1), 1-16.

Halai, A. (2008). Politics and practice of learning mathematics in multilingual classrooms: Issues for policy and practice. In R. Barwell (Ed.), Multilingualism in mathematics classrooms: Global perspectives (pp. 47-62). Multilingual Matters.

Komarek, K. (1997). Mother tongue education in Sub-Saharan countries: Conceptual and strategic considerations. GTZ.

Malone, S. (2003). Education for multilingualism and multi-literacy in ethnic minority communities: The situation in Asia. Paper presented at the conference on Language development, language revitalization, and multilingual education in minority communities in Asia, Bangkok, Thailand. http://www.sil.org/asia/ldc/plenary_papers/susan_malone.pdf

Mansoor, S. (2005). Language planning in higher education. A case study. Oxford University Press.

Mansoor, S., Zafar, M., Hussain, N., Sikandar, A., Azam, S.I., \& Tatari, S.K. (2005). English and employment in Pakistan (Unpublished summary report). Aga Khan University, Centre of English Language.

Nekatibeb, T. (2007). The impact of learning with the mother tongue on academic achievement: A case study of grade 8 students in Ethiopia. In H. Coleman (Ed.), Language and development: Africa and beyond (p.65-78). British Council.

Panah, K. (2000). Teaching and learning school science through the medium of English in Pakistan. (Unpublished master's thesis). Aga Khan University, Institute for Educational Development.

Phillipson, R. (1992). Linguistic imperialism. Oxford University Press.

Phillipson, R. (2001). English for globalization or the world's people? International Review of Education, 47(3), 185-200.

Rahman, T. (1996). Language and politics in Pakistan. Oxford University Press.

Rahman, T. (2002). Language, ideology, and power. Oxford University Press.

Rahman, T. (2003). Language policy, multilingualism, and language vitality in Pakistan. Retrieved on $3^{\text {rd }}$ September, 2011 from http://www.sil.org/asia/ldc/parallel_papers/tariq_rahman.pdf

Shah, D. (2003). Country report on decentralization in the education system of Pakistan: Policies and strategies. Academy of Educational Planning and management. Ministry of Education, Government of Pakistan. http://www.aepam.edu.pk. 
Skutnabb-Kangas, T. (2000). Linguistic genocide in education-or worldwide diversity and human rights? Lawrence Erlbaum.

Smith, K.J. (2003). Minority language education in Malaysia: Four ethnic communities' experiences. International Journal of Bilingual Education and Bilingualism, 6(1), 52-65.

Stroud, C. (2007). Bilingualism: Colonialism, post-colonialism, and high modernity. In M. Heller (Ed.), Bilingualism: A social approach (pp. 205-229). Palgrave Press.

Swada, Y. \& Lokshin, M. (2001). Household schooling decisions in rural Pakistan. Policy Research Working paper series no.2541. The World Bank. Retrieved on September 2, 2011 from http://www-wds.worldbank.org/external/default/WDSContentServer/IW3P/IB /2001/03/09/000094946_01022405385911/Rendered.

Tollefson, J.W. \& Tsui, A. B. M. (2004). Contexts of medium-of instruction policy. In J. W. Tollefson, and A.B.M. Tsui, (Eds.), Medium of instruction policies. Which agenda? Whose agenda? (pp. 283- 294). Lawrence Erlbaum.

Tucker, G. R. (1998). A global perspective on multilingualism and multilingual education. In J. Cenoz, \& F. Genesee, (Eds.), Beyond bilingualism: Multilingualism and multilingual education, (pp. 3-16). Multilingual Matters.

UNESCO. (2007). UIS statistics in brief: Education in Pakistan. http://stats.uis.unesco.org/unesco/ TableViewer/document.aspx?ReportId=121\&IFlanguage=eng\&BR_Country=5860\&BR_Reg ion $=40535$ 